\title{
School Well-Being pada Siswa Berprestasi Sekolah Dasar yang Melaksanakan Program Penguatan Pendidikan Karakter
}

\author{
Faizah, Jovita Nabila Prinanda, Ulifa Rahma, Yuliezar Perwira Dara \\ Universitas Brawijaya, Ketawanggede, Kec. Lowokwaru, Kota Malang \\ email: faizah_hermawan@ub.ac.id
}

\begin{abstract}
The aim of this study was to evaluate school well-being of achieving students in primary school that implement character education programs. This research used qualitative method, data was collected by using interview and observation with 2 primary subjects achieving student on academic or non academic skill, and 5 secondary subjects were teacher, parent, peer of primary subjects. Data was analyzed by Analysis Interactive Model with triangulation source validity. School well-being consists of four dimensions: having, loving, being, and health. The result of this study describes school well-being of achieving student in primary school with character education program.
\end{abstract}

Keywords: school well-being, achieving student, character education programs

\begin{abstract}
Abstrak
Penelitian ini bertujuan untuk menggambarkan school well-being pada siswa berprestasi di sekolah dasar yang melaksanakan program Penguatan Pendidikan Karakter (PPK). Penelitian ini menggunakan metode kualitatif dengan pengumpulan data penelitian melalui wawancara dan observasi terhadap 2 subjek primer siswa sekolah dasar yang memiliki prestasi secara akademik maupun non akademik, pemilihan subjek berdasarkan rekomendasi dari guru sekolah yang memahami siswanya dengan diperkuat data dari 5 subjek sekunder yaitu guru, orangtua dan teman sebaya dari kedua subjek primer. Analisis data yang digunakan ialah analysis interactive model dengan keabsahan data triangulasi sumber. Penelitian ini akan menggali data berdasarkan komponen school well-being pada siswa berprestasi yakni having, loving, being, dan health. Hasil penelitian menunjukkan bahwa dengan penerapan PPK di sekolah tidak menghambat siswa berprestasi untuk merasa sejahtera selama berada di sekolah.
\end{abstract}

Kata kunci: school well-being, siswa berprestasi, penguatan pendidikan karakter

\section{Pendahuluan}

Program penguatan pendidikan karakter merupakan program baru yang diberlakukan oleh Menteri Pendidikan Kebudayaan Republik Indonesia (Mendikbud RI) atau masyarakat umum mengatakan sebagai sekolah fullday school dimana hal tersebut telah disesuaikan dengan Peraturan Menteri Pendidikan dan Kebudayaan Republik Indonesia Nomor 23 Tahun 2017 tentang Hari Sekolah bahwa beban kerja guru dalam satu minggu ialah empat puluh jam, sehingga dengan pembelajaran delapan jam per hari maka pelaksanaan sekolah hanya lima hari saja (Detik News, 2016). Pendidikan karakter yang akan didapat siswa selama di sekolah merupakan nilai-nilai kewarganegaraan dan moral yang dapat diterapkan dalam kehidupan sehari-hari, seperti kedisiplinan, kepatuhan, serta ketaatan dalam mematuhi aturan-aturan yang berlaku dalam masyarakat (Rawana, Frank, Brownlee, Rawana \& Neckoway, 2011; Mumpuni, 2018). Selain itu, dengan menerapkan pembelajaran selama delapan jam di sekolah (fullday school system), pendidikan karakter akan disisipkan secara tidak langsung seperti mengajarkan anak untuk dapat mandiri di sekolah dan meningkatkan kesadaran diri untuk kegiatan spiritual di sekolah (Danil, 2018).

Program penguatan pendidikan karakter ini dimuat dalam kurikulum 2013, dimana dalam kurikulum serangkaian proses pembelajaran yang terdiri dari dua komponen utama, yakni perencanaan dan 
pelaksanaan kegiatan pembelajaran (Rustaman, dalam Fauziah, 2011). Selain itu, Program Penguatan Pendidikan Karakter (PPK) ini juga berbasis tematik, dimana jumlah mata pelajaran yang diajarkan pada siswa hanya enam mata pelajaran yang meliputi Pendidikan Agama; Pendidikan Pancasila dan Kewarganegaraan; Bahasa Indonesia; Matematika; Seni Budaya dan Prakarya (SBDP), serta Pendidikan Jasmani, Olahraga, dan Kesehatan (Mulyasa, 2015).

Proses perencanaan di kurikulum 2013 ini berupa melakukan seleksi kompetensi yang sesuai dengan indikator-indikator evaluasi untuk menentukan kesuksesan pencapaian kompetensi tersebut yang menggunakan pendekatan tematik. Pelaksanaan kurikulum ini sendiri dimulai dari pengenalan konsep tematik dan menumbuhkan proses pembelajaran yang kondusif untuk siswa. Proses pembelajaran ini diwujudkan dalam bentuk pembelajaran kontekstual (contextual teaching and learning) dan bermain peran (Mulyasa, 2015). Selain itu, dalam proses pembelajaran ini juga membimbing siswa untuk dapat mandiri di sekolah serta meningkatkan kesadaran diri untuk meningkatkan aktivitas beribadah siswa di sekolah (Danil, 2018).

Hasil-hasil penelitian yang mendukung adanya system fullday school, menunjukkan bahwa sistem PPK atau disebut fullday school memiliki keefektifan yang tinggi untuk pendidikan karakter, terutama pada siswa SD apabila disertai dengan adanya dukungan instruksional dari berbagai pihak di sekolah (Benawa, Peter, \& Makmun, 2018). Begitu juga, menurut Hincapie (2016) bahwa sistem ini dapat meningkatkan prestasi siswa karena siswa dapat mempelajari banyak hal di sekolah dan dapat meningkatkan keterampilan mereka. Alanshori (2016) juga turut menjelaskan bahwa sekolah sehari penuh menerapkan konsep dasar berupa kegiatan dan kurikulum terpadu. Intensifikasi sistem tersebut untuk meningkatkan prestasi belajar siswa.
Namun di sisi lain, penerapan sistem PPK atau fullday school dianggap hanya dapat memfasilitasi perkembangan kognitif siswa, namun tidak dapat memfasilitasi perkembangan afeksi diri siswa (Herawati dan Kartika, 2008) dan dapat menyebabkan stres, dikarenakan durasi belajar yang terlalu panjang (Susilawati, 2014). Penelitian Refliandra dan Muslimin (2011) menyebutkan bahwa, tingkat stres pada siswa SD dengan sistem fullday lebih tinggi (82.90\%) dibandingkan dengan siswa SD dengan sistem halfday school (43.93\%). Dampak lainnya, sebagaimana penelitian yang dilakukan oleh Tambunan dan Degeng (2017) memaparkan bahwa kemungkinan yang akan terjadi di sekolah adalah adanya tuntutan orang tua dalam hal kenyamanan fasilitas dan pelayanan terhadap siswa apabila sekolah tidak menunjang fasilitas untuk sistem pembelajaran siswa di sekolah. Hal tersebut senada dengan hasil penelitian Sobri (2017), bahwa kesiapan fisik dan mental sangat diperlukan dalam penerapan fullday school agar siswa merasa nyaman, tidak tertekan, lebih-lebih stres mengingat panjangnya jam sekolah.

Prestasi sendiri dapat dilihat secara akademik dan non-akademik. Prestasi akademik siswa merupakan kemampuan siswa dalam belajar dan mengingat pengetahuan yang didapatnya serta mengkomunikasikannya dalam bentuk lisan maupun tulisan saat ujian (Kpolovie, Igho Joe, \& Okoto, 2014). Prestasi non-akademik merupakan prestasi yang diperoleh dari aktivitas olahraga, seni, dan musik (Hillman dkk., 2009). Siswa dengan prestasi nonakademik akan memiliki kesempatan untuk mengembangkan minat dan bakat, kemampuan, dan menguasai teknik-teknik seperti teknik olahraga (Nafi'ah \& Suryanto, 2014).

Sejumlah prestasi yang telah diraih siswa tentu tak lepas dari peran sekolah di dalamnya. Prestasi yang diraih oleh siswa asal SD Joannes Bosco Yogyakarta misalnya, prestasi siswa tersebut telah meraih prestasi dalam bidang olahraga dan seni 
seperti lomba futsal dan paduan suara, sekolah ini juga akan mendatangkan guru pembimbing ekstrakurikuler dari luar sekolah dan akan melengkapi fasilitas sarana prasarana agar siswa semakin serius dalam pembelajaran di sekolah (Tribun Jogja, 2018). Prestasi olahraga dari sekolah lain juga diraih oleh siswa asal Kota Probolinggo yang memegang juara 3 dalam Kejuaraan Nasional Catur Ke-46 di Bogor. Siswa tersebut menuturkan bahwa salah satu pendukung atas keberhasilannya ialah tersedianya ekstrakurikuler catur di sekolahnya (Jawa Pos Radar Bromo, 2017).

Prestasi dari segi akademik lainnya juga diraih siswi asal Jakarta yang berhasil memperoleh nilai sempurna dalam ujian nasional tingkat Sekolah Dasar tahun 2012. Siswa tersebut menjelaskan bahwa prestasinya didukung dari tersedianya buku di sekolah dan kegemarannya dalam membaca buku. Selain itu, metode pembelajaran dari guru yang baik menjadi faktor pendukung lain atas prestasinya (DetikNews, 2012).

School well-being menjadi hal yang penting untuk siswa di sekolah. Konsep school well-being Konu dan Rimpela dibahas oleh Konu dan Koivisto (2011) bahwa school well-being pada siswa meliputi kondisi sekolah, hubungan sosial, self-fulfillment, dan status kesehatan yang berperan dalam proses belajar di sekolah. Dalam hal ini, konsep school well-being siswa dapat menjadi pertimbangan sekolah sebagai bahan agar dapat memahami halhal apa saja yang mampu membuat siswa merasa senang dan sejahtera saat di sekolah (Nidianti \& Desiningrum, 2017). Konu dan Lintonen (2006) juga menjelaskan bahwa dengan adanya school well-being, siswa dapat mengutarakan pendapat mereka tentang lingkungan sekolah sehingga memungkinkan sekolah untuk dapat memahami pendapat dan apa yang dirasakan siswa selama berada di sekolah. Konu dan Koivisto (2011) menjelaskan bahwa empat dimensi dalam school wellbeing merupakan model yang fit yakni having, loving, being dan health. Penjelas- an perdimensi berikut ini tetap mengacu pada uraian dari Konu, Alanen, Lintonen, dan Rimpelä (2002) karena tidak ada perubahan konsep dari evaluasi school well-being pada siswa sekolah dasar oleh Konu dan Koivisto (2011), meliputi kondisi sekolah (having) yaitu kondisi sekolah meliputi lingkungan fisik di dalam sekolah. Lingkungan tersebut ialah lingkungan tempat kerja yang dapat diukur dari tingkat keamanan, kenyamanan, kebisingan, ventilasi, temperatur, kebersihan. Dalam lingkungan fisik ini juga meliputi bagaimana keadaan kurikulumnya, jadwal jam belajar di sekolah, dan hukuman serta terdapat pula layanan yang tersedia untuk siswanya seperti layanan makan siang, kesehatan, dan konseling. Hubungan sosial (loving) yaitu hubungan sosial meliputi pembelajaran di dalam lingkungan dengan melihat dari hubungan antara siswa dengan guru, hubungan pertemanan antar siswa, dinamika kelompok, kasus bullying, hubungan antara sekolah dengan rumah siswa, pengambilan keputusan di sekolah, dan suasana dari organisasi yang ada di sekolah. Pemenuhan diri (being), menurut Allardt dalam kajian Konu \& Rimpelä, arti dari being merujuk pada masing-masing orang sebagai bagian dari masyarakat. Dalam lingkup sekolah, being dapat dilihat dari bagaimana sekolah menawarkan untuk pemenuhan diri. Setiap siswa perlu menyadari pentingnya menjadi bagian dari sekolah. Hal tersebut memungkinkan setiap siswa yang ada di sekolah dapat berpartisipasi dalam pengambilan keputusan di sekolah, dan aspek lainnya di sekolah. Kesempatan untuk meningkatkan pengetahuan dan mengasah keterampilan siswa sendiri terhadap minatnya merupakan hal yang krusial, dimana pengalaman pembelajaran yang positif dapat meningkatkan pemenuhan diri. Status kesehatan (health) yaitu dilihat dari aspek fisik dan aspek mental. Aspek fisik dilihat dari abnormalitas pada bagian tubuh seseorang yang dilihat secara ilmu medis. Sedangkan aspek mental dilihat dari perasaan yang dialami 
seseorang. Konu \& Rimpelä memasukkan aspek status kesehatan (health) secara terpisah karena dalam konteks kesejahteraan (well-being) yang dilihat ialah kesehatan individu secara umum meskipun dipengaruhi oleh kondisi eksternal. Hal ini juga didukung oleh Allardt dalam kajian Konu \& Rimpelä, bahwa hasil analisis statistiknya menunjukkan kesehatan merupakan hal yang berbeda dengan aspek lainnya pada siswa. Bagaimanakah school well-being pada siswa berprestasi sekolah dasar yang saat ini menjalankan program penguatan pendidikan karakter (PPK) di sekolahnya.

\section{Metode Penelitian}

Penelitian ini merupakan penelitian kualitatif dengan pendekatan fenomenologi yakni fenomena yang sedang terjadi pada ranah pendidikan yang menerapkan program penguatan pendidikan character (PPK) atau biasa dikenal dengan fullday school system. Pengumpulan data menggunakan wawancara semi terstruktur dan observasi narative recording dalam menggali informasi school well-being kepada siswa yang berprestasi dan kepada significant other yaitu guru, orang tua ataupun teman sebaya. Panduan wawancara mengacu pada 4 dimensi school well-being Konu dan Rimpela yang telah dievaluasi kembali oleh Konu dan Koivisto (2011) meliputi having, loving, being dan health. Contoh pertanyaan wawancara "Bagaimana pendapat kamu tentang lingkungan sekolah saat ini?", "Seperti apa peran lingkungan sekolah dalam membantu kamu belajar?". Analisis yang digunakan ialah analysis interactive model Miles dan Huberman dengan keabsahan data menggunakan triangulasi sumber.

Subjek primer dalam penelitian ini sejumlah 2 siswa berprestasi dipilih menggunakan purposive sampling dengan karakteristik siswa Sekolah Dasar kelas tinggi (kelas IV dan kelas V), berjenis kelamin laki-laki, bersekolah di Sekolah Dasar yang telah melaksanakan program PPK, dan memiliki prestasi akademik (merupakan siswa dengan nilai tertinggi di kelas) atau prestasi non-akademik (pernah menjuarai kejuaraan/perlombaan/pertandingan di luar sekolah), sedangkan subjek sekunder dalam penelitian ini sebagai data pendukung dipilih berdasarkan orang-orang terdekat dari subjek primer seperti ibu kandung, wali kelas, dan teman dari subjek primer. Subjek dalam penelitian ini ialah subjek RF dari SD Negeri $X$ di Malang dengan prestasinya mengikuti klub sepak bola di luar sekolah yang memenangkan beberapa pertandingan bersama timnya dan subjek AF dari SD Negeri Y di Malang dengan prestasinya berupa nilai tertinggi di kelas.

\section{Hasil dan Pembahasan}

Wawancara pada penelitian ini dilakukan sebanyak dua kali pada subjek primer dan satu kali pada subjek sekunder. Pada subjek pertama yakni subjek RF dilengkapi dengan subjek sekunder yakni ibu, wali kelas, dan teman, sedangkan pada subjek kedua yakni subjek AF dilengkapi dengan subjek sekunder yakni wali kelas dan teman.

\section{Subjek 1 (RF)}

Subjek RF merupakan siswa laki-laki kelas 5 SD Negeri X di Malang. Subjek berusia 11 tahun dan memiliki satu orang adik perempuan yang masih berusia 22 bulan. Subjek memiliki prestasi di bidang olah raga yaitu sepak bola. Subjek telah tergabung dalam sebuah klub sepak bola di kota Malang yaitu Sawojajar FC dan memenangkan kejuaraan liga bola.

Having. Subjek RF merasa bahwa lingkungan sekolah luas dan fasilitas pembelajaran sudah mencukupi serta tersedianya bola plastik dan gawang yang dapat digunakan subjek untuk bermain sepak bola di sekolah, namun ada beberapa hal yang kurang terawat atau terjaga kebersihannya seperti kondisi kamar mandi yang masih banyak sampah dan bau yang menyengat serta fasilitas Unit Kesehatan Sekolah (UKS) yang kurang dalam 
menyediakan obat-obatan untuk siswa. Dengan kondisi ini, bagi RF tidak menjadi penghambat dalam aktivitas belajar sepak bola di sekolah. Walaupun menurut $\mathrm{RN}$ (wali kelas), subjek RF seringkali terlihat kurang konsentrasi ketika di kelas, hal tersebut mungkin disebabkan kegiatan di luar sekolah yang diikuti subjek RF sudah cukup menguras tenaganya.

"Ya... Nyaman gitu, luas (sekolah)...ada perpustakaan buku pelajaran aja..jarang kesana." [RF, W1, 16042018, 82].

"Ya kayak sampah jajan itu dibuang ke kamar mandi." [RF, W1, 16042018, 122].

"Kadang-kadang ada yang nggak disiram hahahaha... Baunya Bu..." [RF, W1, 16042018, 124].

"Enak, (lapangan) luas buat main futsal." [RF, W1, 16042018, 139].

"Ada bola, gawang. Tapi bal e bedo... Lek disini kan... Di lapangan itu bola yang buat sparing, kalo di sekolah bolanya plastik. Podo ae...cuma bal'e enteng" [RF, W5, 20072018, 17-18].

"Ya enak, bisa main sepak bola terus. Kalo sertifikatnya banyak nanti bisa bantu buat ke SMP.” [RF, W5, 20072018, 58-59].

"Kalo lingkungannya luas itu sangat luas ya, cuma kebersihannya di sini kurang mbak. Karena terlalu luas, tenaganya juga sedikit ya jadi kurang maksimal kebersihannya." [RN, W2, 18042018, 2628].

"Ya misalnya piket dan juga anaknya nggak ngerjakan PR gitu tak suruh... PR nya apa, misalnya matematika ya, "Wes kamu tugasnya di rumah buat kubus buat temen-temennya.". Ya kayak gitu, pokoknya istilahnya hukuman itu sesuai dengan bidangnya yang dia langgar." [RN, W2, 18042018, 83-86].

Loving. Dilihat dari bagaimana subjek RF berteman di sekolah, subjek merasa dekat dengan siswa laki-laki di kelas V SD serta sering bermain sepak bola di lapangan bersama teman-teman dari kelas lain, teman-teman subjek hanya mengetahui prestasi subjek dalam skala besar saja. Namun di sisi lain, ketika ada teman yang mengejek/ mengolok-olok, maka RF cenderung tidak menghiraukan sehingga tidak berdampak secara personal bagi diri RF. Hubungan antara subjek dengan guru serta hubungan guru/wali kelas dengan orang tua tergolong baik karena ada media penghubung yakni grup di media sosial. Hubungan dengan orang-orang yang ada di sekitarnya, membantunya mengembangkan minat dalam sepak bola.

"Kalo aku deketnya sama anak yang lakilaki. Kalo anak perempuannya banyak yang pacaran itu, kayak CBR CBR-an gitu, pelakor gitu." [RF, W1, 16042018, 296297].

"Sangat nyaman, enak kalo sama teman." [RF, W1, 16042018, 308].

"Kalo yang Danone itu (teman-teman di sekolah) tau semua... Kalo... Kalo cuma sparing (teman-teman di sekolah) nggak tau." [RF, W5, 20072018, 67].

"Kadang-kadang itu diperhatiin guru, kan guru itu nggak sama karakternya jadi ada yang jalan-jalan merhatiin sama liat-liat, ada yang cuma duduk tok." [RF, W1, 16042018, 303-304].

" $R F$ itu berteman semua ya dengan anakanak itu, kan buat kayak grup-grup sendiri." [RN, W2, 18042018, 117-118].

"Pernah itu cuman salah titik.diilokilokno, "Wah, goblok! Colo!" gitu-gitu." [RF, W1, 16042018, 326].

"Lek aku dia ngomong-ngomong itu tak tinggal pergi." [RF, W1, 16042018, 327].

Being. Selama masa sekolah subjek RF jarang menerima pekerjaan rumah (PR) dalam bentuk soal-soal, biasanya pekerjaan rumah atau tugas yang diterima ialah mengerjakan latihan di LKS (Lembar Kerja Siswa) serta membuat prakarya sesuai dengan tema yang diajarkan pada saat itu. Subjek juga memiliki nilai yang baik yaitu perolehan nilai di atas rata-rata. Subjek tidak menerima penghargaan dari sekolah ketika ia memenangkan suatu pertandingan disebabkan prestasi yang diraihnya merupakan prestasi bersama klub di luar sekolah, namun sekolah meminta subjek untuk 
membawa sertifikat kemenangan sebagai dokumentasi untuk sekolah.

"(Tugas) Tentang... Biasanya itu di LKS sama Mat itu." [RF, W1, 16042018, 349].

"Enggak (merasa kesulitan), soalnya ada yang bantuin." [RF, W1, 16042018, 351].

"Kan di les-lesan itu ada kakak kelas di anak kakak kelas 6 tapi nggak sekolah disini, kadang-kadang dibantu kalo nggak kakak kelas, guru-guru les." [RF, W1, 16042018, 353-355].

"Kalo saya ya (nilainya) di atas ratarata." [RF, W1, 16042018, 361].

"Nggak (diberi penghargaan dari sekolah), kadang-kadang sama disana itu dikasih sertifikat buat bantu naik ke SMP 21." [RF, W1, 16042018, 387-388].

"Biasae "selamat ya"... Terus besok disuruh bawa sertifikat mau difoto di ruang guru." [RF, W5, 20072018, 47].

Health. Subjek RF jarang terkena penyakit batuk maupun flu/pilek, namun ia sering-kali merasa sakit di seluruh badan setelah pertandingan, hal ini disebabkan saat pertandingan di lapangan baik tim subjek maupun lawan sering bertabrakan dan saling menindih ketika jatuh. Namun demikian subjek tetap semangat dan terus melanjutkan aktivitas bermain sepak bola. Subjek pernah mengalami sakit lambung yang membuatnya terhenti dari kegiatan sepak bola, namun saat ini sudah tidak pernah merasakan sakit lambung tersebut.

"Nggak pernah (susah tidur), kalo tidur ya langsung tidur. Walaupun minum kopi lek tidur yo tidur." [RF, W1, 16042018, 463464].

"Panas, flu, sama batuk, sama lambung." [RF, W1, 16042018, 479].

"Dulu itu sakit lambung itu berhenti lama nggak bisa main, soale pas sakit itu lari e nggak bisa banter." [RF, W5, 20072018, 71-72].

"(Sekarang sudah) Enggak (sakit lambung)." [RF, W5, 20072018, 80]

"Kalo aku habis turnamen pernah (sakit) soalnya itu banyak yang mbody, terus kalo jatuh itu ketindihan. Tetep aja main... seneng main bola" [RF, W1, 16042018, 487-488].

\section{Subjek 2 (AF)}

Subjek AF berusia 10 tahun merupakan siswa dengan nilai tertinggi dan saat ini duduk di kelas IV SDN Y daerah Malang. Subjek merupakan siswa pindahan dari luar kota dan bersekolah di SDN Malang pada saat kelas III. Subjek memiliki satu orang kakak dan satu orang adik, yang mana adiknya juga bersekolah di sekolah yang sama dan saat ini duduk di bangku kelas II.

Having. Subjek AF berpendapat bahwa lingkungan sekolah sudah bagus, tetap merasa nyaman dan bisa belajar di sekolah walaupun kelas masih cenderung kurang terang apabila tidak menggunakan lampu. Fasilitas yang dapat digunakan oleh subjek di kelas berupa buku paket, dan lembar kerja siswa (LKS) yang dapat memban-tunya memahami pelajaran, pembelajaran di kelas terkadang menggunakan LCD. Unit kesehatan siswa (UKS) yang cukup memadai, walaupun dengan mahasiswa Jurusan Kedokteran, dan dalam satu semester mendapatkan makan siang gratis dari paguyupan sekolah. Kondisi kamar mandi masih ada yang kotor, serta meja siswa banyak yang sudah bolong pada bagian loker/ laci bawah meja. "(Lingkungan sekolah) bagus. Nyamannyaman ajah ya sekolah" [AF, W1, 04042018, 66].

"Ya kalau nggak pake lampu gelap." [AF, W1, 04042018, 83].

"Ya ada sebagian yang sudah bolong lacilacinya...ada yang gak bisa dipake.” [AF, W1, 04042018, 87].

"(Kamar mandi) ada yang bersih ada yang enggak.” [AF, W1, 04042018, 97].

“ada LCD, Buat pelajaran juga." [AF, W1, 04042018, 164].

"Ya buku cetak tapi ditinggal di sekolah, nggak boleh dibawa pulang. Kalau yang dibawa pulang itu cuma LKS...masih bisa belajar." [AF, W3, 24072018, 38-39].

"(Fasilitas UKS) Udah (mencukupi)." [AF, W1, 04042018, 175]. 
"Kayak dokter tapi yang masih anak-anak" [AF, W1, 04042018, 183]

"Ya kadang-kadang dapat (makan siang dari sekolah)." [AF, W1, 04042018, 199]

Loving. Subjek AF memiliki beberapa teman bermain di kelas. Wali kelas seringkali memberi kepercayaan pada subjek untuk mengajarkan teman-temannya yang masih belum paham pada mata pelajaran matematika. Hubungan wali kelas dengan orang tua berjalan dengan baik melalui whatsapp. Subjek merupakan ketua kelas dan memiliki beberapa teman bermain di sekolah. Subjek tidak pernah menjadi korban maupun pelaku bullying di sekolahnya.

"Ya nyatet-nyatet yang rame kalo di masjid, habis itu nyiapkan kalo mau berdoa itu disiapkan." [AF, W1, 04042018, 258259].

"Karena ketua kelas tapi kadang-kadang wakil juga menyiapkan gantian.” [AF, W3, 24072018, 13].

"Ada...teman bermain di sekolah yang sering bareng-bareng." [AF, W1, 04042018, 279].

"Ee... Tidak... Kalau di kelas itu kadang bantu teman mengerjakan." [AF, W3, 24072018, 45].

"Ya bantu... teman dibantu... Disuruh baca lagi soalnya nanti kalau... dia bingung tanya ke saya." [AF, W3, 24072018, 4748].

"Iya. Kalau nggak bisa itu saya disuruh bu guru ngajarin ke teman-teman." [AF, W3, 24072018, 54].

"Dikerjakan bersama tapi sambil ngomong... Ngomong... Cara ngerjakannya." [AF, W3, 24072018, 58].

"Nggak pernah gitu ke temen (dibully)." [AF, W1, 04042018, 291].

"Nggak pernah juga (mem-bully), tapi cuman tau." [AF, W1, 04042018, 295].

"Sering kok (komunikasi orang tua dengan wali murid)." [AF, W1, 04042018, 307]. "Mengerjakan LKS, membaca LKS. Kalau di rumah itu dibuatkan soal sama mama... Aku yang mengerjakan terus dikoreksi mama." [AF, W3, 24072018, 20-21]
Being. Terkait prestasi dan pemenuhan diri, subjek AF mendapat dukungan dari guru dan orang tua. Subjek juga sering belajar di rumah, subjek dilibatkan membuat prakarya untuk menghias kelasnya dalam acara go green.

"Enggak ada tambahan (bimbingan untuk mempersiapkan ujian)..belajar di rumah biasane” [AF, W1, 04042018, 348].

"Iya sering (mendapat dukungan dari guru) dan orangtua juga." [AF, W1, 04042018, 361].

"iya dikasih selamat bu guru terus disuruh belajar lagi biar nanti bisa tertinggi lagi nilainya." [AF, W3, 24072018, 29].

"Senang karena nilainya bagus semua.termasuk mama." [AF, W3, 24072018, 31].

"(Pembuatan peraturan sekolah) Dari guru-guru...ikut aja” [AF, W1, 04042018, 381].

"Ikut ekskul catur, al-banjari, sama karate." [AF, W1, 04042018, 385].

"..kalo yang buat gantungan dan lainnya itu waktu go green." [AF, W1, 04042018, 435].

Health. Subjek AF sering merasa gugup ketika tampil di depan umum, namun hal itu masih bisa diatasi sendiri. subjek juga terkadang mengalami batuk pilek saat cuaca tidak mendukung, namun hal itu tidak memengaruhi prestasinya di kelas.

"Ya, sering (nervous saat hendak tampil)...ya tarik nafas aja habis itu sudah" [AF, W1, 04042018, 441].

"(Terakhir tidak masuk sekolah) Hmm... Semester lalu...sakit panas pilek" [AF, W1, 04042018, 451].

"(Saat sakit) Tidak...masih bagus nilainya (mempengaruhi nilai).” [AF, W3, 24072018, 63]

"Ya, kalau musim..sering (batuk dan pilek).” [AF, W1, 04042018, 507].

Hasil pada penelitian ini menunjukkan bahwa kedua subjek dengan situasi kondisi dan jenis prestasi yang berbeda, terlihat tetap menjalani aktivitas dengan nyaman 
walaupun ada beberapa kendala seperti fasilitas maupun kesehatan yang sebenarnya tidak menghambat keduanya untuk terus meraih prestasi sesuai bidangnya.

School well-being pada siswa sekolah dasar yang menjalankan program penguatan pendidikan karakter (PPK) atau dikenal dengan fullday school, hasil tentang kesejahteraan siswa di sekolah berupa having, loving, being dan health pada kedua subjek sebagai bagian penting dalam menjalani peran siswa, hal ini karena sosok siswa (karakter) berprestasi itu sendiri yang dapat beradaptasi dengan baik sehingga merasa sejahtera di sekolah.

Pada komponen having, kondisi sekolah meliputi lingkungan fisik yang ada di dalam sekolah seperti keamanan, fasilitas, kurikulum, dan sebagainya yang akan membantu siswa Konu, Alanen, Lintonen, dan Rimpelä (2002). Kedua subjek menyatakan bahwa lingkungan sekolah sudah mencukupi untuk membantunya dalam proses belajar seperti terdapatnya fasilitas pembelajaran di kelas yakni buku paket yang digunakan di sekolah tanpa dibawa pulang oleh siswa, sehingga buku paket hanya dapat digunakan selama di sekolah namun buku kerja siswa (BKS)/ lembar kerja siswa (LKS) dapat dimanfaatkan sebagai media belajar di rumah yang diberikan oleh sekolah setiap semesternya. Selanjutnya pajangan-pajangan di kelas yang sudah disediakan oleh sekolah maupun yang dibuat oleh para siswa sebagai bagian penugasan kelas juga bermanfaat sebagai penunjang belajar siswa karena pada pajangan-pajangan tersebut memuat ringkasan-ringkasan materi menarik yang lebih mudah untuk dipahami, LCD di kelas juga sering digunakan saat pembelajaran untuk menampilkan materi-materi yang bersifat multimedia. Pada subjek RF, sekolah menyediakan bola plastik dan gawang yang dapat digunakan siswa untuk bermain sepak bola di sekolah.

Terpenuhinya kebutuhan siswa terkait sarana dan prasarana belajar mampu memengaruhi keberhasilan belajarnya baik secara akademik dan non akademik (Kudari, 2016) menyatakan faktor pendukung untuk mencapai prestasi akademik siswa dapat berupa jam belajar di sekolah, fasilitas pembelajaran yang digunakan sehari-hari, kompleksitas materi pembelajaran, peran guru dalam mengajar, serta teknologi yang tersedia di ruang kelas. Fasilitas untuk prestasi non akademik siswa dapat berupa pilihan ekstrakurikuler yang tersedia di sekolah dan lingkungan sosial dimana siswa itu berada.

Namun begitu, kondisi yang ada di lapangan tidak se-ideal yang diharapkan seperti ruang kelas masih terasa padat dengan jumlah siswa melebihi batas ketentuan (satu kelas lebih dari 30 siswa) dan panas karena sekolah tersebut masih belum memenuhi rekomendasi dari Dinas Pendidikan yang menyatakan bahwa jumlah maksimal siswa pada satu kelas ialah 28 anak. Terdapat pula, beberapa hal di luar proses pembelajaran yang masih kurang seperti kebersihan di sekitar lapangan sekolah serta kondisi kamar mandi yang kurang terjaga kebersihannya sehingga sering menimbulkan bau yang menyengat. Kondisi lapangan yang kotor karena masih banyak sampah-sampah plastik makanan, hal tersebut tidak menjadi penghambat siswa-siswa untuk bermain di lapangan setiap hari seperti sepak bola dan permainan benteng (bentengan). Dengan kondisi lingkungan tersebut bukan menjadi halangan bagi kedua siswa untuk dapat beraktivitas menjalankan tugas sebagai siswa berprestasi karena dukungan dari lingkungan sosial yang lebih menyeluruh masih diterimanya. Iksan (2013) memaparkan bahwa keberhasilan siswa dalam mencapai prestasi berkaitan dengan terpenuhinya berbagai dukungan, diantaranya dukungan dari lingkungan sosialnya.

Keamanan pada dua sekolah tersebut secara keseluruhan memiliki kondisi yang baik, yang mana pada SD Negeri $X$ dan SD Negeri $Y$ terdapat penjaga sekolah dan seluruh sekolah juga dilengkapi pos satpam. Dengan adanya keamanan di 
sekolah dapat membuat siswa tenang dan dapat melaksanakan aktivitas belajar tanpa khawatir. Keamanan di sekolah berfungsi untuk mengontrol akses keluar masuknya siswa, guru, dan staff sekolah serta pengunjung dari luar yang akan memasuki sekolah sehingga setiap orang yang akan melewati batas pintu sekolah perlu melakukan konfirmasi pada penjaga terkait keperluannya di dalam maupun di luar sekolah (Jennings, Khey, Maskaly, \& Donner, 2011).

Selanjutnya, kedua sekolah tersebut dengan menerapkan PPK (fullday school) pembelajaran sekolah sampai sore hari, namun sekolah tidak memberikan fasilitas makan siang untuk siswa-siswinya, sehingga siswa-siswi membawa bekal masing-masing dari rumah atau dapat membeli di kantin sekolah. Oleh karena itu tentu akan lebih mudah apabila anak membawa bekal makanan sendiri dari rumah yang telah disiapkan oleh orang tua (Nelson, 2013).

Pada komponen loving, kedua subjek memiliki teman bermain di kelas yang mereka bentuk sendiri ke dalam kelompokkelompok kecil di kelas. Subjek RF dengan prestasinya dalam sepak bola sering bermain sepak bola di lapangan sekolah bersama teman-teman kelas yang lain. Lain halnya pada subjek AF dengan prestasinya sebagai siswa yang memiliki nilai akademik tinggi di kelas, AF diberi kepercayaan oleh wali kelas untuk mengajari dan menjelaskan kembali kepada teman-temannya yang masih belum memahami pelajaran. Selain itu, teman-teman subjek $\mathrm{RF}$ dan $\mathrm{AF}$ mengetahui prestasi yang telah diraih, namun untuk subjek RF teman-temannya hanya mengetahui prestasinya dalam skala besar seperti pada pertandingan sepak bola nasional.

Terkait hubungan pertemanan yang mereka jalin, masih terdapat tindakan bullying pada subjek RF. Kasus bullying yang terjadi merupakan bullying yang berbentuk verbal berupa ejekan. Ejekan yang diterima subjek RF berupa ejekan yang merujuk pada istilah-istilah kasar dalam bahasa Jawa, namun dengan ejekan tersebut RF tidak pernah mempermasalahkannya dan tidak memengaruhi hubungan pertemanan dan juga prestasinya. Sedangkan pada subjek AF tidak pernah terlibat dalam tindakan bullying yang terjadi di sekolah. Pada penelitian Konu dan Lintonen (2006) dalam dimensi loving mendapatkan hasil bahwa hampir seluruh subjek memiliki teman dan hanya terdapat satu pertiga yang terlibat dalam kasus bullying. Hal tersebut menandakan bahwa kasus bullying masih terjadi dalam interaksi teman sebaya di sekolah sebagaimana penelitian oleh Dewi, Hasan, dan AR (2016) pada siswa SD di Aceh Besar juga menunjukkan bahwa masih banyak siswa kelas IV dan V yang mengalami bullying, yaitu sekitar lebih dari 50\% dari 40 siswa.

Terkait hubungan siswa dengan guru, kedua subjek memiliki hubungan yang dekat dengan wali kelas dimana ketika ada waktu senggang wali kelas sering mengontrol kondisi kelas. Wali kelas juga mengetahui bagaimana karakteristik dan kebiasaan masing-masing siswanya. Sedangkan hubungan wali kelas dengan orang tua siswa, kedua sekolah menggunakan media berbasis online untuk berkomunikasi dengan orang tua yaitu grup whatsapp. Melalui grup tersebut, hubungan guru/ wali kelas dengan orang tua tetap terjaga dengan baik karena guru dapat menginformasikan segala hal yang berkaitan dengan anak di sekolah. Bentuk dari komunikasi yang dibangun oleh guru dan orang tua tersebut merupakan komunikasi dua arah dimana akan mengembangkan kepercayaan dan apresiasi satu sama lain. Selain itu menjalin komunikasi melalui teknologi terkini dapat meningkatkan kualitas hubungan dengan kemudahan-kemudahan yang ditawarkan melalui teknologi tersebut (Graham-Clay, 2005).

Komponen being pada siswa, sejauhmana pemenuhan diri siswa atau selffulfillment berfokus pada permasalahan siswa yang terkait dengan pekerjaan di 
sekolah seperti bagaimana persiapan ujian, tugas atau pekerjaan rumah (PR), prakarya dan keterampilan, pengambilan keputusan di sekolah, serta dorongan/ apresiasi dari sekolah terhadap siswanya (Konu dkk. 2002). Pada dimensi being ini kedua sekolah tidak menyediakan kelas tambahan khusus untuk siswanya ketika menjelang ujian tengah semester maupun ujian kenaikan kelas. Segala bentuk pembelajaran menjelang ujian akan diserahkan langsung kepada orang tua sehingga anak dapat belajar sendiri di rumah.

Bentuk apresiasi dari sekolah kepada kedua subjek yang berprestasi tersebut beragam. Pada subjek RF, sekolah memberikan pujian dan ucapan selamat, serta mengumumkan serangkaian prestasi terbaru yang telah diraih oleh siswa tersebut pada saat upacara. Pada subjek AF, prestasi peraih nilai tertinggi di kelas pada setiap semester tidak diumumkan pada saat pelaksanaan upacara, melainkan hanya diumumkan di kelas. Hal ini disebabkan tidak seluruh kelas menerapkan dan membuat daftar urutan nilai seluruh siswa di kelas masing-masing, sehingga namanama peraih nilai tertinggi di kelas hanya akan muncul dan akan dibuat sesuai dengan permintaan orang tua. Segala bentuk apresiasi yang diberikan kepada siswa membuat kedua siswa merasa senang dan bangga karena merasa dihargai telah berhasil meraih prestasi di luar sekolah maupun sebagai peraih nilai tertinggi. Uraian-uraian di atas telah sesuai dengan hasil penelitian Konu dan Koivisto (2011) dimana cakupan terkait dengan pemenuhan diri siswa dapat berupa apresiasi, pujian, serta dukungan dari guru, partisipasi siswa dalam kegiatan sekolah, serta pilihan kegiatan dan mata pelajaran dari sekolah.

Siswa juga terlibat aktif dalam aktivitas sekolah sebagai bagian dari pemenuhan diri sebagai siswa, kedua subjek pernah membuat prakarya yang beragam, seperti tirai dari origami untuk jendela, membuat patung dari koran bekas, dan membentuk plastisin. Seluruh prakarya tersebut merupakan bentuk dari tugas-tugas sesuai tema yang diajarkan di sekolah dan juga untuk kegiatan menghias kelas dalam rangka go green. Peran siswa dalam pemenuhan diri ini ialah siswa dapat belajar dan sukses dalam pembelajarannya di sekolah dan sekolah menyediakan tempat atau wadah untuk siswa dapat meningkatkan perannya di sekolah (Konu, Alanen, Lintonen, dan Rimpelä, 2002).

Selanjutnya pada kegiatan ekstrakurikuler yang ditawarkan oleh sekolah terbagi menjadi dua jenis yaitu bersifat wajib dan pilihan. Pada ekstrakurikuler wajib seluruh siswa diwajibkan untuk mengikutinya, dimana pada seluruh sekolah yang menjadi lokasi penelitian seluruhnya mewajibkan siswanya untuk mengikuti ekstrakurikuler pramuka di sekolah yang dilaksanakan sebanyak satu kali dalam satu minggu. Ekstrakurikuler wajib merupakan kegiatan rutin yang harus diikuti oleh seluruh siswa di sekolah, selanjutnya siswa diperkenankan untuk dapat memilih ekstrakurikuler pilihan atau bebas sesuai dengan minatnya (Dahliyana, 2017). Pada ekstrakurikuler pilihan, kedua siswa dibebaskan untuk memilih ekstrakurikuler sendiri dan diperbolehkan untuk memilih lebih dari satu ekstrakurikuler pilihan yang ditawarkan sekolah, dimana subjek RF memilih ekstrakurikuler karate dan sepak bola sedangkan subjek AF memilih ekstrakurikuler catur, seni musik keagamaan dan karate. Pada kegiatan ekstrakurikuler ini juga difungsikan sebagai kegiatan yang menunjang selain dari pendidikan formal dan sebagai wadah untuk mengembangkan potensi peserta didik (Djafri, 2008).

Pada komponen health, kesehatan siswa dalam lingkup sekolah secara ringkas dilihat dari dua aspek yang mencakup tentang penyakit yang diderita siswa dan perasaan yang dirasakan siswa (Konu dkk. 2002). Kedua subjek menyatakan bahwa pernah tidak masuk sekolah karena sakit. Sakit yang paling sering diderita yaitu demam, batuk, dan pilek. Pada subjek RF pernah menderita sakit lambung yang 
membuatnya tidak dapat mengikuti pembelajaran di sekolah dan kegiatan klub sepak bola selama beberapa waktu yang cukup lama. Kedua subjek juga tidak merasa lelah selama berada di sekolah sampai sore hari karena menurut subjek, selama proses pembelajaran di sekolah berlangsung mereka dapat menghabiskan waktu bersama teman-teman dengan berbagai macam kegiatan seperti bermain dan makan bersama sehingga jadwal sekolah yang padat akan terasa menyenangkan bagi mereka apabila dilakukan bersama teman-teman yang lain. Sedangkan kondisi psikologis kedua subjek tidak merasa tertekan dengan pembelajaran di sekolah sampai sore hari dan tidak merasa tertekan terhadap ejekan-ejekan yang diterimanya di sekolah, sehingga dengan penyakit yang diderita dan perasaan yang dialami subjek selama di sekolah tidak menghambat subjek dalam berprestasi di sekolah.

\section{Simpulan dan Saran}

Berdasarkan hasil analisis school wellbeing pada siswa berprestasi sekolah dasar yang menjalankan PPK/ fullday school system dapat disimpulkan bahwa kedua subjek adalah sosok pribadi yang dapat beradaptasi dengan situasi yang ada, sehingga merasa nyaman untuk belajar dan terus berprestasi.

Pada aspek having, kedua subjek merasa bahwa sekolah memiliki fasilitas yang dianggap sebagai sesuatu yang dapat menunjang prestasinya di sekolah dan tidak mempermasalahkan kondisi-kondisi lain yang kurang sesuai di sekolah seperti kebersihan kamar mandi dan fasilitas Unit Kesehatan Siswa.

Pada aspek loving, kedua subjek memiliki hubungan yang baik dengan guru dan teman sebaya walaupun bullying berupa ejekan terkadang masih terjadi pada salah satu subjek. Namun demikian hal tersebut tidak menghambat dan tidak memengaruhi subjek dalam berprestasi. Pihak sekolah dan orang tua juga menjalin hubungan yang baik melalui media group online sehingga orang tua dapat memantau perkembangan anak setiap hari di sekolah.

Pada aspek being, kedua siswa merasa senang dan bangga dengan dirinya dengan tetap aktif mengikuti ekstrakurikuler atau kegiatan yang melatih keterampilan diri melalui tugas-tugas berbentuk prakarya, serta terdapatnya apresiasi berupa dukungan, pujian, ucapan selamat dari guru.

Pada aspek health, kedua subjek pernah menderita sakit panas, batuk, dan pilek, atau sakit lainnya serta muncul rasa gugup saat tampil di depan umum, namun hal tersebut tidak membuat subjek terhambat dalam prestasinya.

Berdasarkan hasil penelitian ini, peneliti selanjutnya diharapkan dapat menggali profil siswa sekolah dasar dalam hal school well-being dengan menjangkau sekolahsekolah yang cakupan situasi kondisinya lebih kompleks seperti sekolah di pedesaan atau yang berada di pinggiran kota sehingga dapat memiliki gambaran school well-being pada siswa sekolah dasar secara lebih variatif.

\section{Daftar Pustaka}

Alanshori, M. Z. (2016). Efektivitas pembelajaran full day school terhadap prestasi belajar siswa. AKADEMIKA, 10(20), 135-150.

Benawa, A., Peter, R., \& Makmun, S. (2018). The effectiveness of full day school system for students' character building. IOP Conference Series: Materials Science and Engineering, 288(1). doi.org/10.1088/1757$899 X / 288 / 1 / 012160$

Dahliyana, A. (2017). Penguatan pendidikan karakter melalui kegiatan ekstrakurikuler di sekolah. Jurnal Sosioreligi, 15(1), 54-64. doi.org/ ejournal.upi.edu/index.php/SosioRelig i/article/download/5628/3821

Danil, M. (2018). Implementation of full day school in Sabbihisma. Jurnal Komunikasi Pendidikan, 2(1), 86-92. 
DetikNews. (2012, Juli 6). Latifa, sang peraih nilai sempurna nilai ujian SD. Diambil kembali dari m.detik.com/news/berita/1959169/latif a-sang-peraih-nilai-sempurna-ujiannasional-sd pada tanggal 31 Mei 2018.

DetikNews. (2016, Agustus 19). Mendikbud: Full day school dongkrak pendidikan kita yang masih rendah. Diambil kembali dari http://news.detik.com/berita/3278860/ mendikbud-full-day-school-dongkrakpendidikan-kita-yangmasih-rendah pada tanggal 19 Desember 2017.

Dewi, N., Hasan, H., AR, M. (2016). Perilaku bullying yang terjadi I SD Negeri Unggul Lampeuneurut Aceh Besar. Jurnal Ilmiah Pendidikan Guru Sekolah Dasar, 1 (2), 37-45.

Djafri, N. (2008). Pengaruh kegiatan ekstrakurikuler terhadap prestasi belajar siswa pada Pesantren AlKhaerat Kota Gorontalo. Jurnal Inovasi, 5(3), 136-150.

Fauziah, Y. N. (2011). Analisis kemampuan guru dalam mengembangkan keterampilan berpikir kreatif siswa Sekolah Dasar kelas V pada pembelajaran Ilmu Pengetahuan Alam. Edisi Khusus, (2), 98-106.

Graham-Clay, S. (2005). Communicating with parents: Strategies for teachers. The School Community Journal, 16(1), 117-129. doi.org/10.1103/PhysRevD.94.104024

Herawati, N. I., \& Kartika, E. (2008). Karakteristik perkembangan sosial emosi siswa SD laboratorium UPI kampus Cibiru dikaitkan dengan sistem pembelajaran full day school. Eduhumaniora: Jurnal Pendidikan Dasar, 1(1), 1-3. doi.org/10.17509/eh.v1i1.2716

Hillman, C. H., Pontifex, M. B., Raine, L. B., Castelli, D. M., Hall, E. E., \& Kramer, A. F. (2009). The effect of acute treadmill walking on cognitive control and academic achievement in preadolescent children. Neuroscience, 159(3), 1044-1054. doi.org/10.1016/j.neuroscience.2009.0 1.057

Hincapie, D. (2016). Do longer school days improve student achievement? Evidence from Colombia. IDB Working Paper Series.

Iksan, M. (2013). Dukungan sosial pada prestasi dan faktor penyebab kegagalan siswa SMP dan SMA. Jurnal Psikoislamik, 10, 53-71.

Jawa Pos Radar Bromo. (2017, Agustus 06). Siswi kelas $1 \mathrm{SD}$ ini juara di kejuaraan nasional catur. Diambil kembali dari radarbromo.jawapos.com/radarbromo/r ead/2017/08/06/05910/siswi-kelas-1sd-ini-juara-di-kejuaraan-nasionalcatur- pada tanggal 31 Mei 2018.

Jennings, W. G., Khey, D. N., Maskaly, J., \& Donner, C. M. (2011). Evaluating the relationship between law enforcement and school security measures and violent crime in schools. Journal of Police Crisis Negotiations, 11(2), 109-124. doi.org/10.1080/15332586.2011.5815 11

Konu, A., Alanen, E., Lintonen, T., \& Rimpelä, M. (2002). Factor structure of the school well-being model. Health Education Research, 17(6), 732-742. doi.org/10.1093/her/17.6.732

Konu, A. I., \& Koivisto, A. M. (2011). The school well-being profile - a valid instrument for evaluation. Proceedings in EDULEARN Conference: 4-7 July 2011, Barcelona, (July), 1842-1850.

Konu, A. I., \& Lintonen, T. P. (2006). School well-being in Grades 4-12. Health Education Research, 21(5), 633-642. doi.org/10.1093/her/cyl032

Kpolovie, J. P., Igho Joe, A., \& Okoto, T. (2014). Academic achievement prediction: Role of interest in learning and attitude towards school. International Journal of Humanities 
Social Sciences and Education, 1(11), 73-100. doi.org/10.1186/1471-23508-S1-S13

Kudari, J. M. (2016). Survey on the factors influences the students' academic performance. International Journal of Emerging Research in Management and Technolog, 5(6), 30-36.

Mumpuni, A. (2018). Integrasi nilai karakter dalam buku pelajaran: Analisis konten buku teks kurikulum 2013. Deepublish: Yogyakarta.

Mulyasa, H. (2015). Pengembangan dan implementasi kurikulum 2013. Bandung: PT Remaja Rosdakarya.

Nafi ' ah, Z., \& Suryanto, T. (2014). Hbungan keaktifan siswa dalam ekstrakurikuler akademik dan non akademik terhadap prestasi belajar siswa kelas VIII SMP Negeri 1 Mojokerto. Kajian Moral Dan Kewarganegaraan, 3(2), 799-813. doi.org/http://jurnalmahasiswa.unesa.a c.id/index.php/jurnal-pendidikankewarganegaraa/article/download/926 $8 / 4026$

Nelson, M. (2013). School food costbenefits: England. Public Health Nutrition, 16(6), 1006-1011. doi.org/10.1017/S136898001200420X

Nidianti, W., \& Desiningrum, D. (2017). Hubungan antara School Well-Being dengan agresivitas. Jurnal Empati, l(1), 248-252.

Rawana, J. R. E., Franks, J. L., Brownlee, K., Rawana, E. P., Neckoway, R. (2011). The aplication of 'a strengthbased approach of student' behaviours to the development of character education curriculum for elementry and secondary schools. The Journal of Education Thought (JET), 45(2) (Autumn, 2011), 127-144.

Refliandra, R., \& Muslimin, Z. I. (2011). Perbedaan tingkat stres antara siswa sekolah dasar yang bersistem full day dan half day. Proyeksi, 6(1), 40-44. Diambil fpsi.unissula.ac.id/images/61zidni immawan 40-44.pdf.

Susilawati, D. (2014). Waktu belajar yang terlalu panjang sebabkan stress di anak. Diambil 22 April 2018, dari /republika.co.id/berita/humaira/ibuanak/14/04/02/n3e5o6-waktu-belajaryang-terlalu-panjang-sebabkan-stressdi-anak.

Sobri, A. Y. (2017). Implementasi pendidikan karakter siswa melalui penerapan full day school: Penerapan full day school dalam multi perspektif, ISBN 978-602-71836-2-9, 16-24.

TribunJogja. (2018, Maret 19). SD Joannes Bosco Yogyakarta terus tingkatkan prestasi siswa. http://jogja.tribunnews.com/2018/03/1 9/sd-joannes-bosco-yogyakarta-terustingkatkan-prestasi-siswa. Diambil kembali pada tanggal 31 Mei 2018.

Tambunan, A. M., A.Y, M. H., \& Degeng, I. N. S. (2017). Strategi kepala sekolah dalam mengelola konflik menyikapi dampak negatif penerapan full day school. Jurnal Pendidikan: Teori, Penelitian, Dan Pengembangan, 2(6), 848-852. 
Psympathic, Jurnal Ilmiah Psikologi Desember 2018, Vol. 5, No. 2, Hal. : 161-174 